\title{
Limitasi Keluar Rumah Bagi Perempuan 'Iddah Wafat dalam Perspektif Maslahah Mursalah
}

\author{
Hasan Baharun dan Syafiqiyah Adhimiy
}

\begin{abstract}
Limitation of Out of House for 'Iddab Wafat Women in the Perspective of Maslahah Mursalah. Although there is no shârih (clear) propotion about the prohibition on going out of the house for a woman who has just been left dead by her husband ('iddah wafat), but jurists of the four Islamic schools have agreed that women who are iddah wafat may not leave the house except in emergencies or in hajiyah (desperate need). But then they differed about the time and limit of the ban. This study examines the prohibition on going out of the house for a woman who has just been left dead by her husband according to the ulema of 'four schools. This study uses descriptive analysis method, with analytical techniques in the form of inductive, deductive and comparative. Based on the results of the study, it can be concluded that women in iddah wafat are allowed to leave the house if there is a need that requires them to leave the house in the morning in hajiyah (needs). While for the night, she may leave the house only at times and in dharâriyah (emergency). Limitation to leave the house for women iddah wafat in hajiyah or dharûriyah conditions is solely for benefit and does not contradict to the principles of maslahah mursalah.
\end{abstract}

Key words: limitation to leave the house, iddah wafat, maslahah mursalah

\begin{abstract}
Abstrak: Limitasi Keluar Rumah Bagi Perempuan 'Iddah Wafat dalam Perspektif Maslahah Mursalah. Meski tidak dijumpai dalil yang shârih tentang larangan keluar rumah bagi perempuan yang baru ditinggal mati oleh suaminya ('iddah wafat), para fukaha empat mazhab telah sepakat bahwa perempuan yang sedang iddah wafat tidak boleh keluar rumah kecuali dalam keadaan darurat atau dalam keadaan hajiyah. Tetapi kemudian mereka berbeda pendapat tentang waktu dan batas larangan tersebut. Penelitian ini menelaah tentang larangan keluar rumah bagi perempuan yang baru ditinggal mati oleh suaminya menurut ulama' empat mazhab. Penelitian ini menggunakan metode deskriptif analisis, dengan tekhnik analisis berupa induktif, deduktif dan komparatif. Berdasarkan hasil penelitian, dapat disimpulkan bahwa perempuan dalam iddah wafat dibolehkan keluar dari rumah jika ada sebab kebutuhan yang mengharuskannya untuk keluar rumah pada pagi hari dalam waktu ikhtiar. Sedangkan untuk malam hari, ia boleh keluar rumah hanya pada waktu dan dalam keadaan darurat. Limitasi kebolehan keluar rumah bagi perempuan iddah wafat dalam kondisi hajiyah atau dharûriyah adalah semata-mata untuk kemaslahatan dan tidak bertentangan dengan batasan prinsip masla $\underline{h} a h$ mursalah.
\end{abstract}

Kata Kunci: limitasi keluar rumah, iddah wafat, maslahah mursalah

Universitas Nurul Jadid Paiton Probolinggo

Karanganyar, Paiton, Probolinggo, Jawa Timur

E-mail: ha5_4n@yahoo.com \& fatihmubarak25@gmail.com 


\section{Pendahuluan}

Islam mengatur keluarga dengan segala perlindungan dan pertanggungan syariatnya. Islam juga mengatur hubungan lain jenis yang didasarkan pada perasaan yang tinggi, pertemuan dua tubuh, dua jiwa, dua hati, dan dua ruh, yakni ikatan sebuah perjanjian perkawinan untuk menjalin kehidupan bersama untuk menggapai sebuah bahtera rumah tangga yang didambakan setiap manusia.

Keluarga adalah rumah tangga yang memiliki hubungan darah atau perkawinan yang menyediakan terselenggaranya fungsi-fungsi instrumental mendasar dan fungsi-fungsi ekspresif keluarga bagi para anggotanya yang berada pada suatu jaringan. Konsep keluarga tersebut tampaknya bersesuaian dengan konsep keluarga dalam masyarakat Indonesia yang memaknai keluarga tidak terbatas pada keluarga inti saja, tetapi juga keluarga batih. ${ }^{1}$

Latar belakang berakhirnya sebuah ikatan perkawinan disebabkan oleh dua faktor. Faktor yang pertama yakni secara horizontal (manusia) dan faktor yang kedua adalah secara vertikal (takdir Tuhan). Ditinjau dari segi horizontal (manusia) putusnya perkawinan dibagi menjadi dua. Dari pihak suami atau yang lebih dikenal dengan sebutan talak. Dari pihak isteri lebih dikenal dengan sebutan khuluk. ${ }^{2}$

Sementara perpisahan dalam perkawinan yang terjadi sebab Allah menakdirkan berpisah adalah dengan jalan kematian salah satu pasangan. Kematian seorang istri tidak menyebabkan konsekuensi hukum dalam waktu jangka panjang. Sedangkan kematian seorang suami menyebabkan konsekuensi hukum dengan limit waktu yang cukup panjang.

Sejak terjadinya perceraian inilah (dalam Islam), mulai adanya masa iddah (masa tunggu) bagi perempuan (istri) dengan berbagai konskuensi yang harus ditanggung, baik secara material, biologis, sampai psikologis. Tujuan 'iddah yang tidak hanya bertujuan untuk mengetahui kebersihan rahim, tetapi ada tujuan lain yang tidak bias gender, yaitu tujuan rekonsiliasi dan berkabung, yang mana mereka harus sama-sama

\footnotetext{
${ }^{1}$ Sri Lestari, Psikologi Keluarga (Jakarta: Kencana, 2012), h. 07.

${ }^{2}$ Tihami, dkk, Fikih Munakahat (Jakarta: Rajawali Pers, 2010), h. 144.
} 
saling melaksanakan dengan sadar. ${ }^{3}$

Masa menunggu setelah perceraian dan kematian suami dikenal dengan istilah 'iddah. Ketentuan 'iddah ini bertujuan antara lain untuk menjaga keturunan, yakni agar janin itu tidak ternodai. ${ }^{4}$ Dalam prinsipnya hukum tentang iddah ketersediaannya di dalam Alquran tidak diragukan lagi mengenai konsensus para ahli hukum dan pengacara. Terddapat beberapa tujuan adanya iddah yakni mencegah pencampuran orang tua, kembali ke suaminya dalam perceraian yang dapat dicabut, melindungi janin, dan menghormati kematian suaminya bagi iddah kematian. ${ }^{5}$ Dalam masa 'iddah wafat, menurut mazhab Syâfi'iyyah, seorang isteri dilarang melakukan hal-hal yang dilarang. Di antaranya adalah pada saat berkabung seorang isteri harus berdiam diri di rumah, kecuali terdapat kebutuhan.

Larangan ke luar rumah bagi mazhab Syafi'i, bagi perempuan iddah, tentu bagi perempuan masa kini menjadi permasalahan yang sangat signifikan. Hal ini dikarenakan perempuan masa sekarang sudah banyak yang beraktifitas di luar rumah, sebagaimana yang dilansir oleh Kompas.com, bahwa Organisasi Buruh Internasional (ILO) mencatat, setiap tahunnya. Pada 2015, 38 persen dari 120 juta pekerja di Indonesia adalah wanita. ${ }^{6}$

Life style, hedonisme dan budaya konsumtif merupakan pemberi pengaruh terbesar bagi kaum perempuan untuk bekerja sebab penghasilan suami sudah tidak dapat mencukupi kebutuhan keluarga, atau bagi perempuan single, dengan budaya masyarakat mandiri sudah tidak ingin lagi bergantung pada pemberian orang tua.

${ }^{3}$ Indar, "Iddah dalam Keadilan Gender," YIN YANG Jurnal Studi Gender dan Anak 5, no. 01, (Juni 2010), h. 02.

${ }^{4}$ Muhammad Yusuf, "Relevansi Pemikiran Ulama Bugis dan Nilai Budaya Bugis (Kajian Tentang 'Iddah dalam Tafsir Berbahasa Bugis Karya Mui Sulsel).” ANALISIS: Jurnal Studi Keislaman 13, no. 1 (2017): h. 57-78.

${ }^{5}$ Fatemeh Mohammadi, dkk, "A Comparative Study of the Iddah (Waiting Period) in Iran Jurisprudence and the Laws of Other Countries," International Research Journal of Applied and Basic Science (IRJABS) 6, no. 2, h. 237.

${ }^{6}$ http://kupang.tribunnews.com/2016/01/07/pertumbuhan-jumlah-pekerja-perempuanmeningkat. Desember 2017. 
Apalagi bagi perempuan yang terlahir dengan ekonomi menengah ke bawah dan dengan anak yang cukup banyak, mau tidak mau perempuan juga harus ikut andil suaminya untuk menghidupi dirinya dan anakanaknya. Sementara untuk menghidupi diri otomatis perempuan tersebut harus beraktivitas di luar rumah, apalagi jika perempuan yang ditinggal mati suaminya tanpa meninggalkan harta warisan. Maka, sekalipun dalam masa 'iddah wafat perempuan harus keluar rumah mencari nafkah untuk sesuap nasi.

Selain itu, perempuan dengan pekerjaan sosial, semisal menjadi Bidan atau Guru juga harus keluar rumah sebelum batas waktu yang ditentukan berakhir. Perempuan yang menjadi guru tidak bisa meninggalkan murid-muridnya dalam masa iddah, karena itu berarti anak-anak tersebut tidak akan menerima pelajaran selama empat bulan sepuluh hari.

Jika perempuan yang bekerja sebagai bidan atau dokter tidak boleh keluar rumah, dapat dibayangkan bagaimana nasib perempuan calon ibu yang akan melahirkan. Sedangkan dalam hukum Islam wajib hukumnya mendatangi dokter perempuan bagi seorang perempuan selagi ada dokter berjenis kelamin perempuan. Tentu bagi perempuan yang akan melahirkan tidak semua perempuan dapat dan mau bersalin di rumah bidan atau rumah sakit, mayoritas perempuan lebih suka bersalin di rumah sendiri dengan mendatangkan bidan.

Perempuan yang menjadi Pegawai Negeri Sipil (PNS), pegawai bank, secara otomatis harus tunduk pada aturan pemerintah atau kontrak, dengan cuti yang sudah disepakati bersama. Pihak pemerintah dan bank tidak akan memberikan cuti selama empat bulan sepuluh hari, karena maksimal cuti bagi PNS dengan alasan genting termasuk di dalamnya kematian hanya berdurasi maksimal dua bulan. Jika perempuan tetap memilih melanjutkan "iddahnya dengan tidak keluar rumah, maka secara otomatis pemecatan akan terjadi, dan hal itu dapat berdampak besar bagi kehidupannya ke depan setelah menjalani masa "iddah.

Kemaslahatan hidup merupakan asas utama dalam pembentukan hukum Islam. Kesukaran dalam hidup hal yang harus dihindari. Untuk 
mencapai kemaslahatan, ada lima hal yang harus dilindungi. Melindungi agama, melindungi diri, melindungi akal, melindungi keturunan dan melindungi harta.

Kemaslahatan hidup yang dimaksud dalam hal ini adalah kemaslahatan yang tidak bertentangan dengan nash hukum Islam. Jika bertentangan tapi dalam keadaan darurat maka sekalipun bertentangan kemaslahatan harus dikedepankan. Demi menjaga dari kelima hal di atas yang wajib dilindungi. ${ }^{7}$

Saat nash yang shârih tidak dijumpai, maka ruang para mujtahid memberikan hukum perbuatan manusia terbuka lebar. Ilmu yang membahas tentang kaidah mengistinbath hukum adalah ilmu ushûl fiqh. Karena yang mampu menjawab permasalahan zaman adalah dengan menggunakan pemahaman fikih secara manhaji bukan lagi qauli. Karena berubahnya sebuah hukum dipengaruhi oleh perubahan zaman dan tempat.

Dalam Ilmu ushîl fiqh, dijelaskan bahwa pensyariatan hukum dalam Islam harus didasarkan pada tujuan untuk memberikan maslahat bagi manusia dengan mencegah masyaqqah dan menghilangkan darûrah.

Mashlahah yang dapat dikembangkan para mujtahid adalah kemaslahatan yang belum tertulis dalam nash dan ijmak, serta tidak ditemukan nash atau ijmak yang melarang atau memerintahkan mengambilnya. Kemaslahatan ini dilepaskan oleh syari' dan diserahkan kepada manusia untuk mengambil atau tidak mengambilnya. Jika kemaslahatan itu diambil oleh manusia, maka akan mendatangkan kebaikan bagi mereka, jika tidak diambil juga tidak akan mendatangkan dosa. $^{8}$

Berkaitan dengan hal tersebut, maka pada dasarnya hikmah `iddah mendatangkan kemaslahatan bagi semua pihak, maka ketika diketahui bersihnya rahim seorang perempuan, sehingga tidak akan tercampur antara keturunan seseorang dengan yang lain, atau dengan kata lain agar tidak terjadi percampuran dan kekacauan nasab, adanya masa sebagai

\footnotetext{
${ }^{7}$ Alaiddin Koto, Ilmu Fikih dan Ushul Fikih (Jakarta: RajaGrafindo Persada, 2004), h. 122.

${ }^{8}$ Alaiddin Koto, Ilmu Fikih dan Ushul Fikih, h. 122
} 
kesempatan kepada suami isteri yang berpisah untuk berpikir kembali, apakah untuk rujuk kembali kepada isterinya ataukah akan meneruskan cerai jika hal tersebut dianggap lebih baik. ${ }^{9}$

Dalam literatur ilmu fikih, ulama mazhab Syâfi'iyyah dan mazhab Hanâfiyah berbeda pendapat tentang limitasi keluar rumah bagi perempuan iddah wafat, baik dari segi jaraknya ataupun dari segi waktunya. Menurut ulama Syâf'iyyah perempuan 'iddah wafat boleh keluar rumah pada pagi hari dalam kondisi darurat sedangkan keluar rumah di malam hari tidak diperbolehkan. Menurut ulama' Hanâfiyah, perempuan iddah wafat boleh keluar siang hari untuk mencari nafkah dan lain sebagainya. Pada malam hari juga diperbolehkan keluar dengan catatan tidak boleh bermalam di rumah orang lain. ${ }^{10}$

Perempuan dalam iddah wafat jika mutlak tidak boleh keluar rumah, maka kemaslahatan manusia akan tercederai dan hal tersebut tidak sejalan dengan asas hukum Islam yang mengedepankan kemashlahatan bagi manusia. Dalam banyak kitab, mazhab Syâf'iyyah mengecualikan bolehnya keluar rumah bagi perempuan 'iddah wafat dengan kata li 'uzrin atau li darûrah. Tentang udzur syar'i, atau darûrah. ${ }^{11}$ Timbul pertanyaan, apa saja hal yang termasuk udzur syar'i atau darûrah? Apakah mungkin hal tersebut akan membawa kemaslahatan bagi manusia? Di dalam beberapa kitab klasik standard tidak dijelaskan apa saja hal-hal yang mungkin bisa masuk dalam kategori tersebut berikut juga waktu yang masuk dalam kategori udzur atau darûrah.

\section{Maslahah Mursalah}

Masla $\underline{\text { ah }}$ mursalah menurut etimologi terdiri dari dua kata, yaitu maslahah dan mursalah. Kata Maslahah berasal dari kata kerja bahasa

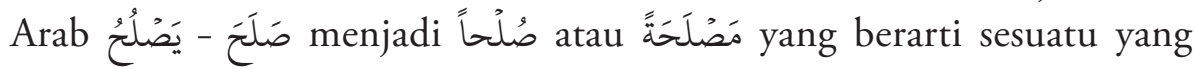
mendatangkan kebaikan. Sedangkan kata mursalah berasal dari kata kerja yang ditasrîf-kan sehingga menjadi isim maf'ûl, yaitu: اَرَسَ - يُرِسِل

9 Siti Zulaikha, “Iddah dan Tantangan Modernitas", Jurnal Hukum Istinbath 7, no. 1, (Mei 2010), h. 96.

${ }^{10}$ Wahbah Zuhaily, Figh Islam wa Adillatuhu, Jilid VII, (Bayrut: Darul Fikr, 2014), h. 615.

${ }^{11}$ Wahbah Zuhaily, Figh Islam wa Adillatuhu, Jilid VII, (Bayrut: Darul Fikr, 2014), h. 616. 


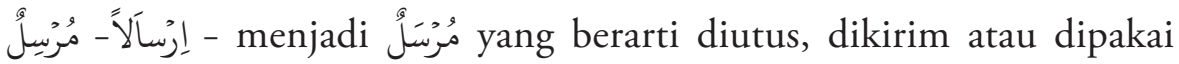
(dipergunakan). ${ }^{12}$

Perpaduan dua kata menjadi maslahah mursalah yang berarti prinsip kemaslahatan (kebaikan) yang dipergunakan menetapkan suatu hukum Islam. Juga dapat berarti, suatu perbuatan yang mengandung nilai baik (bermanfaat). ${ }^{13}$

Definisi lain mengenai masla $\underline{h a h}$ mursalah secara bahasa adalah maslahah berarti manfaat dan kebaikan, sedang mursalah berarti lepas. ${ }^{14}$

Sedangkan menurut terminologi, beberapa pakar berpendapat, antara lain sebagai berikut:

Menurut Muhammad Hasbi Ash-Siddiqi, masla $\underline{h a h}$ ialah:

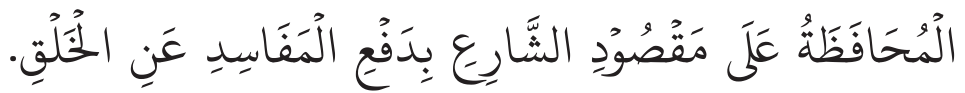

"Memelihara tujuan syara" dengan jalan menolak segala sesuatu yang merusakkan makhluk." "I

Menurut Imam al-Râzi, masla $\underline{h a h}$ adalah sebagai berikut:

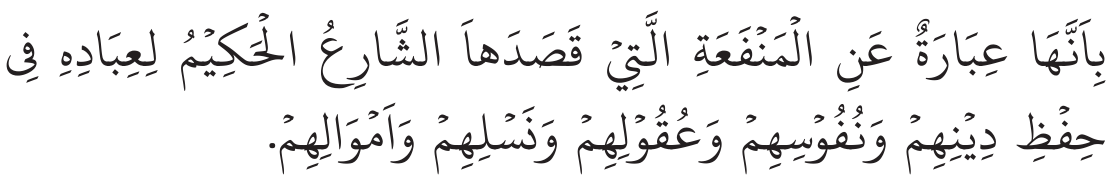

"Maslahah adalah perbuatan yang bermanfaat yang telah diperintahkan oleh musyarri' (Allah) kepada hambaNya tentang pemeliharaan agamanya, jiwanya, akalnya, keturunannya, dan harta bendanya." ${ }^{16}$

Imam al-Syatibi mengemukakan definisi masla $\underline{h a h}$ dengan sesuatu yang dipahami untuk memeliharanya sebagai suatu hak hamba, dalam bentuk meraih kemaslahatan dan menolak kemafsadahan yang untuk mengetahuinya tidak didasarkan pada akal semata, jika Allah tidak memberikan penegasan terhadapnya, bahkan menolaknya, maka kaum

\footnotetext{
${ }^{12}$ Abdur Rahman Dahlan, Ushul Fiqh (Jakarta: Kencana, 2010), h. 148.

${ }^{13}$ Chaerul Umam, dkk, Ushul Fiqih (Bandung: CV. Pustaka Setia, 2000), h. 135.

${ }^{14}$ Amir Syarifuddin, Ushul Fiqh, Jilid II, (Jakarta: Kencana, 2009), h. 345.

${ }^{15}$ Hasbi As-Siddiqi, Pengantar Hukum Islam, Vol. 01, (Jakarta: Rajawali, 2009), h. 236

${ }^{16}$ Fakhruddin al-Razi, Al Mahsul, Jilid II, (Bayrut: Dar Kattab Ilmiah, t.t.), h. 434.
} 
muslimin sepakat menolaknya sebagai kemaslahatan. ${ }^{17}$

Dengan demikian dapat ditarik benang merah bahwa maslạhah mursalah adalah kemaslahatan yang tidak ditetapkan oleh syara' dalam penetapan hukum dan tidak ada dalil yang melarang kemaslahatan tersebut.

Masląhah dilihat dari adanya keserasian dan kesejalanan anggapan baik oleh akal dengan tujuan syara' dalam menetapkan hukum, ditinjau dari usaha mencari dan menetapkan hukum, maslạhah terbagi menjadi tiga macam, ${ }^{18}$ yaitu:

\section{Maslahah Mu'tabarah}

Maslabah mu'tabarah merupakan kemaslahatan yang diperhitungkan oleh Syâri'. Dalam artian ada petunjuk dari Syâri', baik secara langsung atau tidak langsung, memberikan petunjuk pada adanya masla $\underline{h} a h$ yang menjadi alasan dalam menetapkan hukum dan dijadikan dasar dalam penetapan hukum. Misalnya kewajiban puasa pada bulan Ramadan, mengandung kemaslahatan bagi manusia, yaitu untuk mendidik manusia agar sehat secara jasmani maupun rohani. Kemaslahatan ini melekat langsung pada kewajiban puasa ramadhan dan tidak dapat dibatalkan oleh siapapun.

Demikian juga kemaslahatan yang melekat pada kewajiban zakat, yaitu untuk mendidik jiwa muzakki agar terbebas dari sifat kikir dan kecintaan yang berlebihan pada harta, dan untuk menjamin kehidupan orang miskin. Kemaslahatan ini tidak dapat dibatalkan, sebab jika dibatalkan akan menyebabkan hilangnya urgensi dan relevansi dari pensyariatan zakat. ${ }^{19}$

\section{Maslahah Mulgah}

Kemaslahatan yang dianggap baik oleh akal, tapi tidak diperhatikan oleh syara' atau ditolak oleh syara' dan ada petunjuk syara' untuk me-

\footnotetext{
${ }^{17}$ Abu Ishak al-Syâthibi, Al-I'tisham, Jilid II, (Bayrut; Dâr al-Mảrîfah, 1975), h. 39.

${ }^{18}$ Amir Syarifuddin, Ushul Fiqh, Jilid II, (Jakarta: Kencana, 2009), h. 350

${ }^{19}$ Amir Syarifuddin, Ushul Figh, Jilid II, (Jakarta: Kencana, 2009), h. 350.
} 
nolaknya. Syara' menetapkan kemaslahatan lain selain itu. Misalnya adalah kemaslahatan perempuan menjadi imam bagi laki-laki yang bertentangan dengan kemaslahatan yang ditetapkan oleh syar’i yaitu pelarangan perempuan menjadi imam bagi laki-laki. Demikian juga kemaslahatan yang diperoleh oleh seorang pencuri, ditolak oleh syar'i dengan mengharamkan pencurian, demi melindungi kemaslahatan yang lebih besar, yaitu kemaslahatan rasa aman bagi masyarakat. ${ }^{20}$

\section{Maslahah Mursalah}

Maslahah mursalah atau yang sering dikenal istishlâh adalah kemaslahatan bagi manusia yang belum tertulis dalam nash dan ijmak, serta tidak ditemukan nash dan ijmak yang melarang atau memerintahkan mengambilnya. Pembentuk hukum dengan cara maslahah mursalah sematamata untuk mewujudkan kemaslahatan manusia dengan mendatangkan manfaat dan menolak kemudaratan dan kerusakan bagi manusia. ${ }^{21}$ Misalnya, pencatatan perkawinan, penjatuhan talak di pengadilan, kewajiban memiliki SIM bagi pengendara kendaraan bermotor, dan lainnya.

Kekuatannya sebagai hujjah dalam menetapkan hukum, ada tiga macam maslahah. ${ }^{22}$ Pertama, maslahah dharuiriyah. Maslabah dharûriyah yaitu segala hal yang menjadi sendi eksistensi kehidupan manusia, harus ada demi kemaslahatan. Bila sendi itu tidak ada atau tidak terpelihara secara baik, kehidupan manusia akan kacau, kemaslahatannya tidak terwujud, baik di dunia maupun di akhirat. Kedua, maslahah hajiyah. Maslabah hajiyah adalah semua bentuk perbuatan dan tindakan yang tidak terkait dengan dasar yang lain (yang ada pada maslahah dharûriyah) yang dibutuhkan oleh masyarakat tetap juga terwujud, tetapi dapat terhindarkan kesulitan dan menghilangkan kesempitan. ${ }^{23}$ Dalam sumber lain menyebutkan bahwa maslạhah hajiyah adalah segala sesuatu yang sangat dihajatkan oleh manusia untuk menghilangkan kesulitan dan

\footnotetext{
${ }^{20}$ Amir Syarifuddin, Ushul Figh, h. 350.

${ }^{21}$ Totok Jumantoro, Kamus Ushul Fikih (Jakarta: Amzah,2009), h. 205.

${ }^{22}$ Alaiddin Koto, Ilmu Fiqih dan Ushul Fiqih (Jakarta: Raja Grafindo Persada, 2004), h. 122.

${ }^{23}$ Amir Syarifuddin, Ushul Fiqh, Jilid II, (Jakarta: Kencana, 2009), h. 349.
} 
menolak segala halangan. ${ }^{24}$ Hajiyah ini tidak rusak dan terancam jika tidak dipenuhi tetapi hanya menimbulkan kepicikan dan kesempitan, dan hajiyah ini berlaku dalam lapangan ibadah, adat, muamalah dan bidang jinâyah.

Ketiga, maslahah tahsiniyah. Maslạhah tahsîniyah adalah menggunakan semua yang layak dan pantas yang dibenarkan oleh adat kebiasaan yang baik. Maslauah tahsîniyah merupakan sebuah tindakan atau sifatsifat yang pada prinsipnya berhubungan dengan etika atau akhlak serta memelihara keutamaan dalam bidang ibadah, adat dan muamalah. ${ }^{25}$ Imam Abu Zahrah menyatakan bahwa termasuk dalam lapangan tahsiniyah adalah melarang wanita-wanita muslimat keluar ke jalan-jalan umum memakai pakaian yang seronok atau perhiasan-perhiasan yang mencolok mata. Sebab hal ini bisa menimbulkan fitnah di kalangan masyarakat banyak yang pada gilirannya akan terjadi hal-hal yang tidak diinginkan oleh keluarga, terutama oleh agama. Selanjutnya dikatakan bahwa adanya larangan tersebut bagi wanita sebenarnya merupakan kemuliaan baginya untuk menjaga kehormatan dirinya agar tetap bisa menjadi wanita yang baik dan menjadi kebanggaan keluarga dan agama di masa mendatang. ${ }^{26}$

Sedangkan ditinjau dari segi perubahannya maslạhah terbagi menjadi dua macam. ${ }^{27}$ Pertama, maslahah tsâbitah. Kemaslahatan yang sifatnya tetap, tidak berubah sampai akhir zaman. Misalnya berbagai kewajiban ibadah seperti salat dan lainya. Kedua, maslahah mutagayyirah. Kemaslahatan yang berubah-ubah sesuai dengan perubahan tempat, waktu, dan subyek hukum. Kemaslahatan seperti ini berkaitan dengan permasalahan muamalah dan adat kebiasaan, seperti makan makanan yang berbeda-beda antara daerah yang satu dengan yang lainnya.

\footnotetext{
${ }^{24}$ Totok Jumantoro, Kamus Ushul Fikih (Jakarta: Amzah, 2009), h. 202.

${ }^{25}$ Amir Syarifuddin, Ushul Figh, Jilid II, (Jakarta: Kencana, 2009), h. 35.

${ }^{26}$ Abu Zahra, Ushul Fiqih (Surabaya: Al Hidayah, t.t.), 140.

${ }^{27}$ Zurifah Nurdin, Ushul Fiqih 1 (Jakarta: Rajawali, 2012), h. 56.
} 


\section{Limitasi Keluar Rumah Bagi 'Iddah Wafat Menurut Ulama}

Pernikahan menurut UU No. 1 tahun 1974 tentang Perkawinan, dilaksanakan demi terbentuknya ikatan keluarga yang berdasarkan pada Tuhan sebagaimana yang termaktub dalam pasal satu yakni: "Perkawinan ialah ikatan lahir bathin antara seorang pria dengan seorang wanita sebagai suami isteri dengan tujuan membentuk keluarga (rumah tangga) yang bahagia dan kekal berdasarkan Ketuhanan Yang Maha Esa". 28

Jika perkawinan yang berlandaskan pada niat beribadah kepada Tuhan, maka sebesar apapun masalah yang dihadapi suami isteri dalam pernikahan tidak akan bisa memisahkan kedua pasangan kecuali kematian. Kematian merupakan salah satu dari dua faktor yang menyebabkan putusnya perkawinan. Faktor yang pertama adalah secara vertikal (takdir Tuhan). Faktor yang kedua yakni secara horizontal (manusia). Ditinjau dari segi horizontal (manusia) putusnya perkawinan dibagi menjadi dua. Dari pihak suami atau lebih dikenal dengan sebutan talak, dari pihak isteri lebih dikenal dengan sebutan khulu'. ${ }^{29}$

Sementara perpisahan secara vertikal dalam perkawinan terjadi sebab Allah menakdirkan berpisah dengan jalan kematian salah satu pasangan. Kematian seorang isteri tidak menyebabkan konsekuensi hukum dengan limit waktu yang panjang. Sedangkan kematian seorang suami menyebabkan konsekuensi hukum dengan limit waktu yang cukup panjang.

Setelah kematian suami, seorang isteri harus menyelesaikan "masa tunggu" sebelum menikah dengan lelaki lain. Masa tunggu atau dalam istilah fikih biasa disebut "iddah adalah masa menanti atau menunggu yang diwajibkan atas seorang perempuan yang diceraikan oleh suaminya (cerai hidup atau cerai mati), yang bertujuan untuk mengetahui kandungan perempuan itu berisi (hamil) atau tidak, ${ }^{30}$ serta untuk

${ }^{28}$ UU No. 1 tahun 1974 tentang Perkawinan (Bandung: Citra Umbara, 2009), h. 02.

${ }^{29}$ Tihami, dkk, Fikih Munakahat (Jakarta: Rajawali Pers, 2010), h. 144.

${ }^{30}$ Diberlakukannya 'iddah karena untuk mengetahui kandungan perempuan itu berisi (hamil) atau tidak, maka Yusuf al-Qaradhâwi mendukung kemajuan teknologi kedokteran, melalui USG. Karena itu seharusnya pula ketetapan tentang masa 'iddah wanita yang dicerai 
menunaikan satu perintah dari Allah Swt. ${ }^{31}$

Alquran telah menjelaskan bagi perempuan yang dicerai mati dalam pernikahan yang sah, baik sudah dikumpuli atau tidak, mengalami haid atau tidak kecuali bagi yang hamil, maka masa iddahnya adalah empat bulan sepuluh hari, sebagaimana firman Allah dalam surat alBaqarah ayat 234 yang artinya "Orang-orang yang meninggal dunia di antaramu dengan meninggalkan isteri-isteri (hendaklah para isteri itu) menangguhkan dirinya (ber iddah) empat bulan sepuluh hari ..."). Empat bulan sepuluh hari tersebut jika dihitung adalah perkiraan dari proses awal terciptanya janin dalam kandungan, yaitu empat puluh hari dalam bentuk cairan sperma, kemudian empat hari berbentuk segumpal darah, lalu empat puluh hari berbentuk segumpal daging, kemudian sepuluh hari berikutnya ditiupkan ruh di dalamnya, maka hikmah dari menunggu itu selain bentuk ta'abbud adalah untuk memastikan kondisi rahim apakah hamil atau tidak. ${ }^{32}$

itu pun yang 'illat-nya untuk mengetahui hamil dan tidaknya wanita yang dicerai itu tidak bisa secara mutlak ditentukan harus selama tiga kali haid. Karena rahasia rahim wanita yang menjadi 'illat bagi masa 'iddah telah diketahui secara gamlang oleh teknologi kedokteran. Lagi pula bagi manusia modern sekarang yang lebih rasional, dalam memutuskan untuk bercerai biasanya didahului dengan proses pisah ranjang yang berbulan-bulan, yang tentunya tidak melakukan persetubuhan (junub) antara pasangan itu, yang bisa menyebabkan kehamilan. Namun tampaknya al-Qaradâwi tidak berani mengabaikan ketentuan Alquran tentang masa 'iddah ini. Dia berhenti di situ dalam pernyataannya yang terbatas dengan menyatakan mendukung kemajuan teknologi. Lihat Badri Khaeruman, "Al-Qaradawi dan Orientasi Pemikiran Hukum Islam untuk Menjawab Tuntutan Perubahan Sosial.” Wawasan: Jurnal Ilmiah Agama dan Sosial Budaya 1, no. 2 (2016), h. 237.

${ }^{31}$ Meskipun demikian, faktanya, masih saja ada di masyarakat yang tidak mengindahkan aturan tersebut, sebagaimana dalam penelitian Habib Ismail, dan Nur Alfi Khotamin. Dalam penelitian tersebut, dijelaskan bahwa seorang perempuan janda (ibu Aisyah) yang ditinggal mati suaminya, belum genap masa iddahnya, sudah melaksanakan perkawinan. Perempuan tersebut melakukan pernikahan dalam masa 'iddah ('iddah mati) karena beberapa faktor. Pertama, faktor pendidikan atau pengetahuan. Faktor ketidaktahuan akan adanya masa iddah dalam Islam. Hal ini menunjukkan bahwasanya ibu Asiyah kurang sekali pemahamannya dalam ilmu agama. Kedua, adalah faktor gangguan eksternal yang biasanya dalam masyarakat disebut sebagai gangguan sihir (pelet) yang dilakukan oleh pihak pria yaitu bapak Plontang untuk menghilangkan alam bawah sadar dari ibu Aisyah untuk mengikuti keinginannya yaitu menikah dengannya. Ketiga, faktor biologis, dan keempat, adalah faktor ekonomi yang menjadikan ibu Aisyah melakukan pernikahan dalam masa iddah tersebut. Inilah permasalahan-permasalahan yang menyebabkan ibu Aisyah melakukan pernikahan tersebut. Lihat selengkapnya Habib Ismail, dan Nur Alfi Khotamin "Faktor dan Dampak Perkawinan dalam Masa Iddah (Studi Kasus di Kecamatan Trimurjo Lampung Tengah).” Jurnal Mahkamah: Kajian Ilmu Hukum dan Hukum Islam 2, no. 1 (2017): h. 135-160.

${ }^{32}$ Rasyida Arsjad, "Iddah, Antara Agama dan Budaya (Studi Kasus Iddah Wafat di 
Dalam masa 'iddah wafat, ada beberapa hak dan kewajiban serta larangan-larangan syar'i yang harus dilaksanakan patuh oleh seorang isteri. Salah satu larangan perempuan dalam iddah wafat adalah tidak bolehnya seorang isteri keluar rumah. Imam Syâfi'i berpendapat untuk perempuan iddah wafat tidak boleh keluar dari tempat iddah kecuali dengan adanya alasan. Imam Syâf'i memutlakkan perempuan dalam 'iddah yang mana saja tidak boleh keluar rumah dengan berlandaskan pada ayat 01 (satu) Surat al-Talaq. Dengan hanya menambahkan jika semua penghuni tempat tinggal bersama suami pindah maka perempuan tersebut diperbolehkan pindah karena darurat. ${ }^{33}$ Dalam perkembangannya, mazhab Syâf'iyyah kemudian memperluas limitasi keluar rumah bagi perempuan iddah wafat dengan kebolehan keluar rumah dengan kebutuhan yang tidak darurat seperti bercakap-cakap.

Sebagaimana dalam kitab Fath al-Muin bahwa perempuan iddah wafat boleh keluar rumah di siang hari untuk membeli semacam makanan, menjual hasil tenunannya, atau mencari kayu bakar. Keluar rumah di malam hari tidak diperbolehkan walaupun baru awal malam. Tetapi ia diperbolehkan keluar malam ke rumah tetangganya yang bergandengan untuk menemani dan bercerita. ${ }^{34}$

Berbeda dengan pendapat Syâfi'iyyah, Hanâfiyah berpendapat dengan merinci masa iddah talak dan wafat. Bagi perempuan dengan iddah talak haram keluar pada malam atau siang hari baik talak raji atau talak bån. Bagi perempuan ‘ddah wafat boleh keluar siang hari untuk mencari nafkah untuk dirinya karena dia sudah tidak mendapatkan

Kecamatan Sangkapura)", Jurnal Lentera: Kajian Keagamaan, Keilmuan dan Teknologi 3, no. 1, (Maret 2017), h. 144. Lihat juga Syh Noorul Madihah Syed Husin, dan Raihanah Azahari, "Pendekatan Islam dalam Memelihara Maslahah Wanita Selepas Kematian Suami." Jurnal Syariah 18, no. 3 (2010), h. 482.

${ }^{33}$ Wahbah Zuhaily, Figh Islam wa Adillatuhu, h. 616. Terkait ayat tentang 'iddah yakni Q.s. al-Baqarah [2]: 234 dan dan al-Talaq [65]: 4 terkesan secara lahiriyah berlawanan. Kekaburan ini dapat dipahami dengan mengetahui latar belakang (asbâb al-nuzĥl) munculnya ayat itu. Lihat lebih lengkapnya dalam karya Ainol Yaqin, "Urgensi Tarjîh dalam Istinbath Hukum Islam.” AlIhkam: Jurnal Hukum dan Pranata Sosial 10, no. 1 (2015), h. 113-114. Lihat juga Ahmad Atabik, "Kontradiksi antar Dalil dan Cara Penyelesaiannya Prespektif Ushuliyyin." YUDISIA: Jurnal Pemikiran Hukum dan Hukum Islam 6, no. 2 (2015), h. 263

${ }^{34}$ Zainuddin Al Maliubury, Fath al-Muin (Surabaya: Al Haramain, t.t.), h. 110. 
nafkah dari suaminya, ${ }^{35}$ dan pada malam hari dengan catatan tidak boleh bermalam di rumah orang lain. Jika di rumah keluarganya sendiri maka diperbolehkan. ${ }^{36}$

Sedangkan mazhab Hambali membolehkan perempuan keluar rumah untuk memenuhi keperluannya di siang hari karena siang hari adalah waktu orang mencari kebutuhan hidup dan jual beli apa yang diperlukannya. Keluar pada malam hari tidak diperbolehkan karena pada malam hari kemungkinan besar akan menimbulkan fitnah dan hal-hal buruk.

Sejalan dengan pendapat mazhab Hambali, mazhab Maliki juga membolehkan secara mutlak perempuan yang sedang menjalani iddah talak atau dalam iddah wafat keluar rumah pada siang hari demi memenuhi kebutuhannya. Mazhab Maliki juga tidak memperbolehkan seorang perempuan dalam masa iddah menginap di rumah orang lain dan tidak boleh keluar pada malam hari kecuali darurat karena banyak kemungkinan buruknya. ${ }^{37}$

Kebolehan keluar rumah bagi perempuan iddah wafat menurut empat mazhab menimbulkan perbedaan pendapat. Mazhab Syâfi'i secara tegas melarang perempuan iddah wafat keluar rumah kecuali karena kebutuhan dimutlakkan sama dengan perempuan iddah talak. Mazhab Hanâfi membedakan perempuan iddah wafat dan talak. Mazhab Hanâfi memperbolehkan keluar rumah juga karena kebutuhan bahkan pada malam hari dengan catatan tidak menginap. Senada dengan mazhab Hanâfi, mazhab Mâliki juga berpendapat demikian bagi perempuan iddah wafat. Mazhab Hambali berpendapat sama dengan mazhab Hanâfi hanya saja mazhab ini membatasi untuk tidak keluar pada malam hari.

Pendapat keempat mazhab di atas, terlihat adanya kesinambungan antar mazhab yakni memperbolehkan keluar rumah bagi perempuan dalam iddah wafat karena kebutuhan perempuan tersebut yang mengharuskan

\footnotetext{
${ }^{35}$ Wahbah Zuhaily, Figh Islam wa Adillatuhu, h. 615.

${ }^{36}$ Sayyid Sabiq, Fiqih Sunnah (Surabaya: Al Haramain, t.t.) h.187.

${ }^{37}$ Wahbah Zuhaily, Figh Islam wa Adillatuhu, h. 610.
} 
untuk keluar rumah. Terlepas mazhab tersebut menyamakan dengan iddah talak ataupun tidak.

Keempat mazhab tersebut juga ada kesejalanan dalam menetapkan waktu keluar rumah, yakni pada pagi hari saat perempuan tersebut dalam waktu ikhtiar dan tidak diperkenankan untuk malam hari karena menghindari bahaya. Berbeda dengan saat berada pada waktu darurat semisal rumah tersebut akan roboh atau ada gangguan lain yang mengancam jiwa perempuan tersebut, maka keluar malam hari diperbolehkan.

Perempuan tersebut di atas boleh keluar rumah karena hajatnya. Jumhur ulama sepakat memperbolehkan tersebut dengan catatan tetap melaksanakan ihdâd yang wajib bagi wanita yang ditinggal mati suaminya, yaitu dengan tidak berhias diri secara berlebihan, tidak memakai sutera, tidak memakai celak dan tidak memakai minyak wangi ketika keluar rumah.

\section{Limitasi Keluar Rumah Bagi Perempuan 'Iddah Wafat dalam Perspektif Maslahah Mursalah}

Para ulama masa dahulu telah mencoba membagi pembidangan ilmu fikih. Ada yang membaginya menjadi tiga bidang yaitu ibadah, muamalah (perdata Islam) dan pidana Islam, ada pula yang membaginya menjadi empat bidang yaitu ibadah, muamalah, munâkahat, dan 'uqûbah.

Walaupun demikian, dua bidang pokok hukum Islam sudah disepakati oleh semua fukaha yaitu bidang ibadah dan bidang muamalah. Bidang muamalah ini kadang-kadang disebut bidang adat yaitu aturanaturan yang dimaksudkan untuk mengatur hubungan manusia sebagai perorangan maupun sebagai golongan, atau dengan perkataan lain, aturanaturan untuk mewujudkan kepentingan-kepentingan duniawi. ${ }^{38}$

Apabila pembidangan itu hanya dua yaitu bidang ibadah dan muamalah, maka pengertian muamalah di sini adalah muamalah dalam arti yang luas, di dalamnya termasuk bidang-bidang hukum keluarga, pidana, perdata, acara, hukum internasional dan lain sebagainya. Sebab

${ }^{38}$ A. Djazuli, Ilmu Figh (Bandung: Orba Shakti, 1991), h. 53. 
ada pula pengertian bidang muamalah dalam arti sempit yaitu hanya meliputi hukum perdata saja. ${ }^{39}$

Terlepas dari pembagian bidang hukum di atas. Ulama membagi hukum menjadi dua bidang tersebut dikarenakan akan berpengaruh pada perkembangan hukum di zaman selanjutnya. Hukum bidang ibadah bersifat ta'abbudy tidak dapat dikembangkan atau berubah karena perbedaan waktu dan tempat berbeda dengan bidang muamalah yang bersifat ta'aqquly, sehingga bisa berubah karena perubahan waktu dan tempat. ${ }^{40}$

Pernikahan dalam hal ini dapat dikategorikan sebagai bidang muamalah bukan ibadah. Dalam proses perkawinan, putusnya perkawinan merupakan sebuah keniscayaan yang tidak dapat dihindari. Salah satu sebab putusnya perkawinan adalah dengan meninggalnya pasangan. Bagi suami yang ditinggal isterinya, tidak ada konsekuensi hukum dengan limit waktu yang panjang, berbeda dengan isteri yang ditinggal suaminya, ia harus patuh pada konsekuensi yang disyari'atkan oleh syara' yakni ia harus berada dalam masa 'iddah. Bagi perempuan yang ditinggal mati oleh suaminya, ia harus menunggu selama empat bulan sepuluh hari sebelum menikah dengan laki-laki lain. Dalam masa tunggu tersebut terdapat kewajiban dan larangan yang berlaku untuk seorang isteri. Salah satu kewajiban perempuan dalam masa iddah wafat adalah tidak boleh keluar rumah. Sayyid Sabiq mengatakan bahwa isteri yang sedang menjalani masa iddah berkewajiban untuk menetap di rumah di mana dia dahulu tinggal bersama sang suami sampai selesai masa 'iddahnya dan tidak diperbolehkan baginya keluar dari rumah tersebut. ${ }^{41}$

${ }^{39}$ Ismail Nawawi, Fikih Muamalah (Bogor: Ghalia Indonesia, 2012), h. 9.

${ }^{40}$ Terkait konsep tảaqquli dan tảabbudi bisa dilihat dalam karya Abdul Qodir Zaelani, "Konsep Ta’aqquli dan Ta’abbudi dalam Konteks Hukum Keluarga Islam." Asas: Jurnal Hukum dan Ekonomi Islam 6, no. 1 (2014). Abdul Mukti Bisri, "Konsep Ta’aqquli dan Ta’abbudi dalam Tafsir," Akademika 8, no. 2 (2014): h. 231-240. La Jamaa, "Konsep Tảabbudi dan Tảaqquli dan Implikasinya Terhadap Perkembangan Hukum Islam.” Asy-Syir'ah 47, no. 1 (2013).

${ }^{41}$ Habib Ismail, dan Nur Alfi Khotamin. "Faktor dan Dampak Perkawinan dalam Masa Iddah (Studi Kasus di Kecamatan Trimurjo Lampung Tengah)." Jurnal Mabkamah: Kajian Ilmu Hukum dan Hukum Islam 2, no. 1 (2017): h. 135-160. 
Ulama berbeda pendapat tentang limitasi keluar rumah bagi perempuan iddah wafat. Perbedaan pendapat tersebut terjadi karena perbedaan penafsiran ayat yang menjadi dasar hukum keluar rumah bagi perempuan iddah wafat. Jumhur ulama berlandaskan pada ayat 01 surat al-Talaq sebagai berikut:

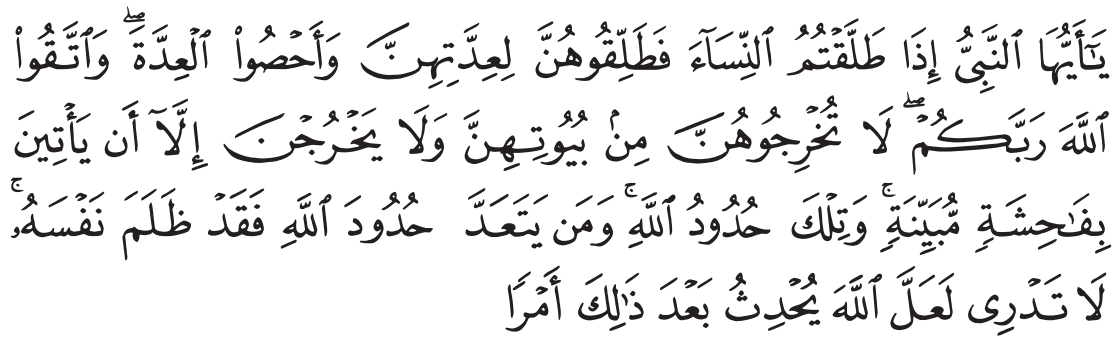

"Hai Nabi, apabila kamu menceraikan isteri-isterimu maka hendaklah kamu ceraikan mereka pada waktu mereka dapat (menghadapai) "iddahnya (yang wajar) dan hitunglah waktu iddah itu serta bertakwalah kepada Allah Tuhanmu. Janganlah kamu keluarkan mereka dari rumah mereka dan janganlah mereka (diizinkan) ke luar kecuali mereka mengerjakan perbuatan keji yang terang. Itulah hukum-hukum Allah, maka sesungguhnya dia telah berbuat zalim terhadap dirinya sendiri. Kamu tidak mengetahui barangkali Allah mengadakan sesudah itu sesuatu hal yang baru".

Keluar rumah menjadi pembahasan yang tidak disentuh oleh Ahmad Musthafa al-Maraghi. Dalam kitab Tafsir Al-Maraghi, hanya dijelaskan limitasi waktu menjalani masa iddah, kebiasaan orang Arab, mereka biasa bertahan tanpa suami dalam kurun waktu empat bulan, larangan berhias dan kebolehan berkabung di atas tiga hari. ${ }^{42}$

Selain dalam ayat al-Talaq ayat 1 (satu), tentang perempuan yang ditinggal wafat oeh suaminya, dalam surat 234 surat al-Baqarah juga sama sekali tidak disinggung permasalahan keluar rumah bagi perempuan iddah wafat. Dijelaskan dalam Tafsir Al-Maraghi hanya keharusan berdiam di rumah tempat tinggal sebelum terjadinya perceraian sampai masa iiddah terlalui. ${ }^{43}$

${ }^{42}$ Ahmad Al-Maraghi, Tafsir Al Maraghi, Jilid II, (Mishr: Mustafa Al Halabi, 1974), h. 329.

${ }^{43}$ Ahmad Al-Maraghi, Tafsir Al Maraghi, Jilid II, h. 329. 
Ayat al-Talaq tersebut di atas, M. Quraish Shihab mengatakan bahwa perempuan yang keluar rumah pada masa iddah tetap tidak diperbolehkan berdandan, seakan memamerkan dirinya, tapi juga tidak harus berpenampilan kusut. Ia dapat tampil secara normal. ${ }^{44}$ Namun, ia juga tidak memperbolehkan perempuan pada masa iddah wafat keluar rumah untuk menghadiri pesta perkawinan dengan menampakkan aneka hiasannya. Kalau perempuan tersebut keluar rumah untuk belajar atau mencari nafkah untuk kebutuhan dirinya dan anak-anaknya maka hal tersebut tidak dilarang.

Selain Alquran, jumhur ulama juga menggunakan hadis yang diriwayatkan oleh Furai'ah sebagai sandaran hukum keluar rumah bagi perempuan 'iddah wafat. Hadis tersebut sebagaimana berikut:

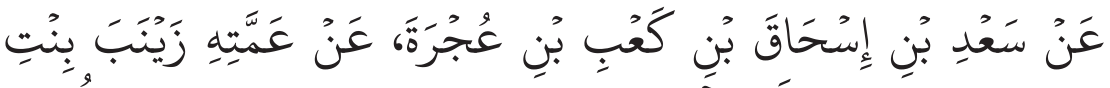

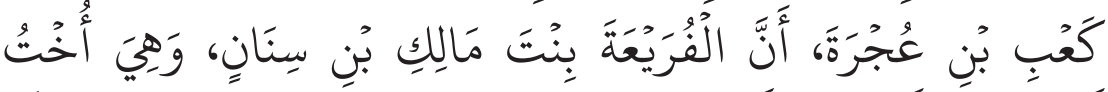

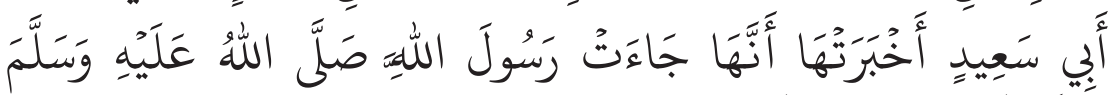

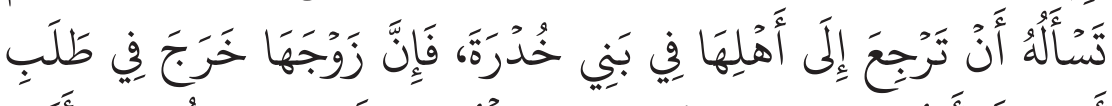

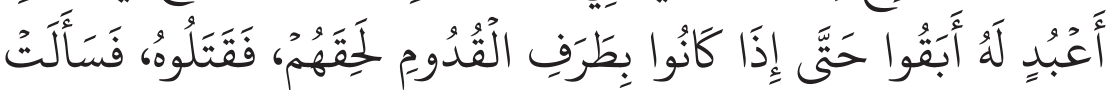

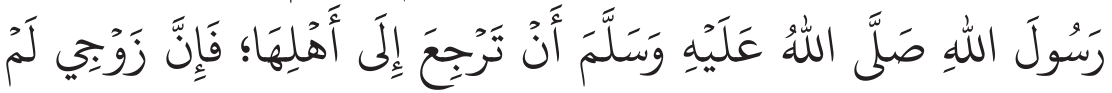

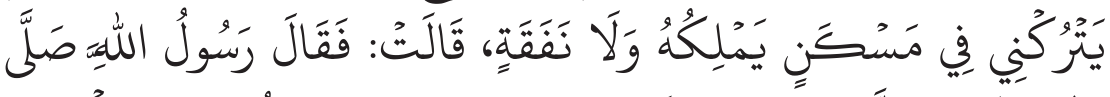

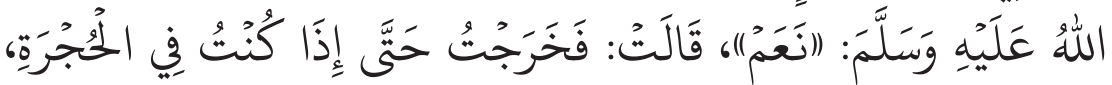

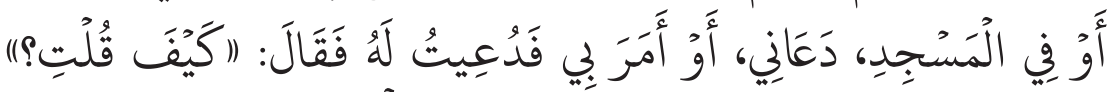

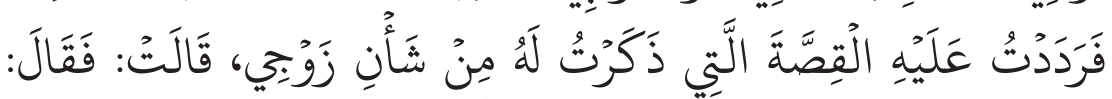

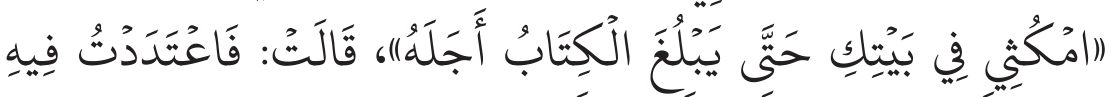

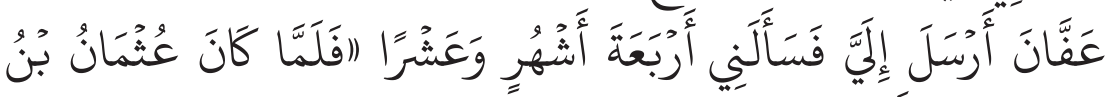

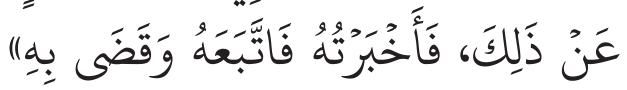

${ }^{44}$ M. Quraish Shihab, Tafsir Al Misbah. Jilid XIII, (Jakarta: Lentera Hati, 2000), h. 190. 
Dari [Sa'd bin Ishaq] berkata, telah menceritakan kepadaku [Zainab binti Ka'b] dari [Furai'ah binti Malik] dia berkata, "Suamiku keluar untuk meminta pertolongan kepada orang-orang kafir, ketika dia sampai dipenghujung jalan, mereka membunuhnya, lalu datanglah pembawa kabar kematiannya kepadaku, sedangkan rumabku jauh dari rumahrumah keluargaku. Lantas aku menemui Rasulullah shallallahu 'alaihi wasallam dan menceritakan akan hal itu, aku katakan, 'Sesungguhnya pembawa kabar kematian suamiku datang kepadaku, sedangkan aku berada di rumah yang jauh dari rumah-rumah keluargaku, dan suamiku tidak meninggalkan untukku nafkah apalagi harta yang akan diwariskannya. Dan dia tidak mempunyai rumah, jika aku pindah ke rumah keluargaku, atau paman-pamanku niscaya akan mempermudah beberapa urusanku." Beliau bersabda: "Pindahlah," ketika aku keluar masjid, atau ke ruanganku, beliau memanggilku atau menyuruh seseorang memanggilku. Maka aku pun dipanggil, beliau lantas bersabda: "Tetaplah di rumah saat pembawa kabar itu datang hingga habis masa "iddahnya." Asma berkata, "Lalu aku menunggu di sana empat bulan sepuluh hari. Kemudian Utsman mengirim kepadaku sesuatu, lalu aku mengabarkannya dan iapun mengambilnya. (H.r. Imam Turmudzi). ${ }^{45}$

Ayat dan hadis tersebut, mazhab Syâfi'i berpendapat bahwa bagi perempuan yang dalam masa iddah wafat tidak boleh keluar rumah kecuali untuk hajat perempuan di siang hari. ${ }^{46}$ Sedangkan mazhab Hanâfi membedakan perempuan iddah wafat dan talak, mazhab Hanâfi memperbolehkan keluar rumah juga karena kebutuhan bahkan pada malam hari dengan catatan tidak menginap. Senada dengan mazhab Hanâfi, mazhab Mâliki juga berpendapat demikian bagi perempuan iddah wafat. Madzhab Hambali berpendapat sama dengan madzhab Hanafi hanya saja mazhab ini membatasi untuk tidak keluar pada malam hari. ${ }^{47}$

${ }^{45}$ Hadits No. 1200, Imam Turmudzi, Sunan al-Turmudzi, Jilid IV, (Bayrut: Dar Kattab Ilmiah, t.t.), h. 310 .

${ }^{46}$ Lihat selengkapnya Jamhuri, dan Izzudin Juliara Izzudin Juliara, "Penggabungan 'Iddah Wanita Hamil dan Kematian Suami (Analisis Terhadap Pendapat Mazhab Syafi'i)." SAMARAH: Jurnal Hukum Keluarga dan Hukum Islam 1, no. 1 (2017): h. 226-247.

${ }^{47}$ Lihat selengkapnya Hartono, "Kompilasi Fatwa Ulama tentang 'Iddah Wanita Hamil 
Diperbolehkannya wanita tersebut keluar rumah dengan catatan dengan tetap melaksanakan ihdâd yang wajib bagi wanita yang ditinggal mati suaminya yaitu dengan tidak berhias diri dan memakai minyak wangi ketika keluar rumah. ${ }^{48}$

Hukum boleh keluar rumah bagi perempuan iddah wafat dalam beberapa hajat seorang perempuan senada dengan ilmu psikologi yang memerlukan perempuan tersebut keluar rumah dalam masa 'iddah untuk memulihkan kondisi emosionalnya. Dalam ilmu psikologi, seorang yang ditinggal oleh kekasihnya rentan mengidap gangguan psikomatic malignan. Gangguan psikosomatik adalah salah satu gangguan jiwa yang paling umum ditemukan dalam praktik umum. Istilah ini terutama digunakan untuk penyakit fisik yang disebabkan atau diperburuk oleh faktor kejiwaan atau psikologis. Beberapa penyakit fisik dianggap sangat rentan diperburuk oleh faktor mental seperti stres dan kecemasan, di antaranya gangguan kulit, muscoskeletal (otot, sendi dan saraf), pernafasan, jantung, kemih, kelenjar, mata dan saraf. Beberapa orang juga menggunakan istilah gangguan psikosomatik ketika faktor kejiwaan menyebabkan gejala fisik, tetapi penyakit fisiknya sendiri tidak ada (tidak dapat dijelaskan secara medis).

Salah satu penjelasan psikosomatik adalah bahwa emosi negatif mempengaruhi sistem otonom tubuh, hormon dan kekebalan terhadap beberapa penyakit. Depresi, kemarahan, dan isolasi sosial berkontribusi terhadap penyakit jantung. Stres di sisi lain, mempengaruhi asma, gangguan pencernaan dan banyak penyakit fisik lainnya. Kondisi emosional tidak stabil yang menyebabkan gangguan psikosomatik tersebut dapat berdampak negatif pada sistem organ vital manusia, sehingga menjadikan seseorang yang ditinggalkan pasangannya jatuh sakit yang progresif dan terminal, dan kemudian "menyusul" pasangannya menghadap Tuhan. Hal tersebut oleh Mathay disebutkan sebagai "black hole". ${ }^{49}$

Karena Zina dan Kebolehan Menikahinya: Studi Komparatif Mazhab Syafi'iyyah dan Mazhab Hanabilah.” PhD diss., Universitas Islam Negeri Maulana Malik Ibrahim, 2012.

${ }^{48}$ Syeikh Mustafa al-Bugha, Al-Fiqhul Manhaji, Jilid IV, (Bayrut: Dar al-Fikr, t.t.), h. 163.

${ }^{49}$ Bacharuddin Jusuf Habibie, Habibie dan Ainun (Jakarta: THC Mandiri, 2012), h. xv. 
Ada tiga alternatif yang disarankan dokter untuk mencegah seseorang jatuh pada hisapan black hole, yakni yang pertama, melakukan "curhat" menceritakan dan mendiskusikan perasaan dan permasalahan yang dialami kepada sejumlah teman dan sahabat agar tekanan emosional dapat release. Kedua, menjalani terapi psikiatris dengan psikoterapi dan minum obat. Ketiga, melakukan kegiatan yang melibatkan secara intensif pikiran maupun emosionalnya..$^{50}$

Dari ketiga tawaran tersebut di atas, semuanya akan lebih intensif jika dilakukan pada suasana kondusif yang mendukung stabilitas emosional seperti di pantai sambil melihat deru ombak atau di cangkruk tengah sawah. Hal tersebut secara otomatis membuat perempuan dalam iddah wafat harus keluar rumah, dan keluar rumah dalam hal ini termasuk dalam kebutuhan perempuan tersebut.

Dalam ketentuan durasi waktu masa tunggu, ketentuan tersebut bersifat ta'abbudy. Tapi untuk ketentuan keluar rumah, ketentuan bersifat ta'aqquly. Karena hal tersebut terkait dengan teknis pelaksanaan dan disebabkan oleh tidak adanya nash secara shârih menjelaskan tentang tidak boleh keluar rumah bagi perempuan iddah wafat.

Dalam ilmu ushûl fiqh sebuah hukum yang tidak memiliki sandaran shârih ayat atau hadis, maka hukum tersebut berlandaskan

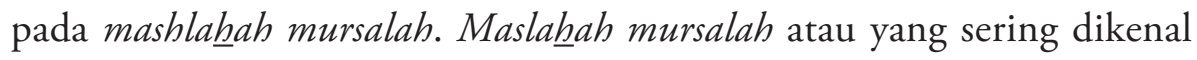
istishlah adalah kemaslahatan bagi manusia yang belum tertulis dalam nash dan ijmak serta tidak ditemukan nash atau ijmak yang melarang atau memerintahkan mengambilnya. Pembentuk hukum dengan cara maslahah mursalah semata-mata untuk mewujudkan kemaslahatan manusia dengan mendatangkan manfaat dan menolak kemudaratan dan kerusakan bagi manusia. ${ }^{51}$

Penggunaan maslahah dalam penentuan dan pelaksanaan hukum dapat terlihat dari adanya kaidah fikih yang berkaitan langsung dengan maslahah, yakni kaidah al-dhararu yuzâl (kemudaratan harus dihilangkan). Kaidah ini menjadi pijakan dasar menggapai semua bentuk maslahah

\footnotetext{
${ }^{50}$ Bacharuddin Jusuf Habibie, Habibie dan Ainun, h. xv.

51 Totok Jumantoro, Kamus Ushul Fikih (Jakarta: Amzah, 2009), h. 205.
} 
dan menolak segala mafsadat. Prinsip yang menjadi pesan inti kaidah ini merupakan poin pokok dan dasar pertimbangan fuqahâ dalam mencetuskan hukum-hukum fikih. ${ }^{52}$

Darurat yang harus dihilangkan tersebut dalam rangka memenuhi hal-hal yang bersifat kebutuhan primer manusia yang bertitik tolak kepada pemeliharaan lima perkara, yaitu agama, jiwa, akal, kehormatan (nasab), dan harta. Islam telah mensyariatkan bagi masing-masing lima perkara itu, hukum yang menjamin realisasinya dan pemeliharaannya. lantaran dua jaminan hukum ini, terpenuhilah bagi manusia kebutuhan primernya. Dalam artian ada keringanan terhadap sebuah hukum jika hukum tersebut dijalankan sebagaimana mestinya akan berdampak pada hilangnya lima perkara tersebut seperti diperbolehkannya memakan bangkai yang haram untuk bertahan hidup, dalam hal ini tujuan dari keringanan boleh memakan makanan haram adalah untuk keselamatan jiwa. ${ }^{53}$

Dalam proses pelaksanaannya, terdapat kaidah fikih al-masyaqqah tajlibu al-taysîr (kesulitan mendatangkan kemudahan) dalam artian bahwa hukum-hukum yang dalam penerapannya menimbulkan kesulitan dan kesukaran bagi mukallaf sebagai subjek hukum, maka syari'ah meringankannya sehingga mukallaf mampu melaksanakannya tanpa kesulitan dan sesukaran. Kaidah ini lantas menjadi rujukan para ulama. Dengan menggunakan kaidah ini sesuai dengan syarat dan ketentuannya maka akan didapati keringanan hukum semisal boleh buka puasa bagi orang yang sedang dalam perjalanan. ${ }^{54}$

Pada prinsipnya kebutuhan dapat berada pada tingkatan darurat sebagaimana kaidah fikih, "kedudukan kebutuhan itu menempati kedudukan darurat". Kebutuhan adalah suatu keadaan yang menghendaki agar seseorang melakukan sesuatu keadaan yang tidak menurut hukum yang seharusnya berlaku karena adanya kesukaran dan kesulitan. Hajat menempati kedudukan darurat saat yang dilanggar adalah hukum haram ligairihi bukan li dzâtihi. ${ }^{55}$

\footnotetext{
${ }^{52}$ A. Djazuli, Kaidah Fikih (Jakarta: Kencana. 2011), h. 56

${ }^{53}$ Imdad Robbani dkk, Formulasi Nalar Figh (Surabaya: Khalista, t.t.), h. 225.

${ }^{54}$ A. Djazuli, Kaidah Fikih, h. 56.

${ }^{55}$ A. Djazuli, Kaidah Fikih, h. 76
} 
Maslahah sebagai hujjah syar'iyah tidak diterima secara mutlak oleh semua ulama. Mazhab Syafi'i dan Hambali menolak menggunakan maslahah mursalah dengan beberapa alasan, salah satunya dengan alasan sikap menjadikan masla $\underline{\text { ahh }}$ mursalah sebagi hujjah menodai kesucian hukum Islam karena memperturutkan hawa nafsu dengan dalih maslahah. Namun pada kenyataannya, Imam Ghazali terbukti menggunakan maslabah mursalah sebab Imam Ghazali merumuskan maslahah sebagai suatu tindakan memelihara syara' atau tujuan hukum Islam. Tujuan hukum Islam menurut Imam Ghazali adalah memelihara lima hal yakni hifdz al-dîn, hifdz al-nafs, hifdz al-'aql, hifdz al-nasl, dan hifdz al-mâl. Setiap hukum yang mengandung tujuan memelihara salah satu dari lima. ${ }^{56}$

Hal di atas disebut maslahah dan setiap yang meniadakannya disebut mafsadah dan menolak mafsadah disebut maslahah. Imam Ghazali membuat batasan operasional maslahah mursalah untuk dapat diterima sebagai dasar untuk menetapkan hukum Islam yaitu:

1. Maslahah tersebut harus sejalan dengan tujuan penetapan hukum Islam yaitu memelihara agama, jiwa, akal, harta dan keturunan atau kehormatan.

2. Maslahah tersebut tidak boleh bertentangan dengan Alquran, Sunnah dan Ijmak.

3. Maslahah tersebut menempati level dharûriyah (primer) atau hajjiyah (sekunder) yang setingkat dengan dharûriyah.

4. Kemaslahatannya harus berstatus qath'i atau zhanny yang mendekati qhati. Dalam kasus-kasus tertentu diperlukan persyaratan, harus bersifat qath'iyyah.

5. Dharûriyah dan kulliyah. ${ }^{57}$

56 Selengkapnya bisa dilihat pada karya Nur Kholis, "Antisipasi Hukum Islam dalam Menjawab Problematika Kontemporer (Kajian Terhadap Pemikiran Maslahah Mursalah alGhazali)." Al-Mawarid 10 (2003). Andi Herawati, "Maslahat Menurut Imam Malik dan Imam al-Ghazali (Studi Perbandingan)." Diktum: Jurnal Syariah dan Hukum 12, no. 1 (2014): h. 42-53. Hayatullah Laluddin, Mohamad Nasran Mohammad, Zuliza Mohd Kusrin, Shofian Ahmad, Zaini Nasohah, Mohd Zamro Muda, Md Yazid Ahmad, and Ahmad Muhammad Husni. "An Analysis on Maslaha's Development Through of al-Ghazali Pre and Post al-Ghazali Periods." International Business Management 6, no. 2 (2012): h. 187-193.

${ }^{57}$ Al-Ghazali, Al-Mustashfa min Ilmil Ushul (Bayrut: al-Risalah, 1997), h. 414. 
Berdasarkan persyaratan operasional yang dibuat oleh Imam Gazali di atas, kelima hal tersebut harus dipenuhi untuk dapat diterimanya maslahah mursalah. Dari kelima batasan tersebut, terlihat bahwa Imam Ghazali tidak memandang maslahah mursalah sebagai dalil yang berdiri sendiri, terlepas dari Alquran, Sunnah dan Ijmak. Imam Ghazali memandang maslahah mursalah hanya sebagai sebuah metode istinbath suatu hukum bukan sebagai dalil atau sumber hukum Islam.

Ruang lingkup operasional maslahah mursalah tidak disebutkan oleh Imam Ghazali secara tegas. Namun berdasarkan contoh-contoh kasus maslahah mursalah yang dikemukakan oleh Imam Ghazali dalam kitab-kitabnya al-Mustashfâ dapat disimpulkan bahwa Imam Ghazali membatasi ruang lingkup operasional maslahah mursalah hanya pada bidang muamalah saja.

Pendapat mazhab tentang kebolehan keluar rumah bagi perempuan iddah wafat tersebut begitu relevan dan dibutuhkan pada masa sekarang. Masa di mana perempuan lebih dituntut banyak beraktivitas di luar rumah seperti menjadi perawat, dosen, polwan dan yang lain. Pendapat ini juga sejalan dengan tujuan awal penetapan hukum yakni untuk kemaslahatan dan menolak mafsadat.

Jika perempuan hanya boleh keluar rumah dalam waktu darurat sebagaimana pendapat imam Syafi'i, maka dapat dibayangkan bagaimana Islam memandulkan produktivitas perempuan sebab terkadang perempuan yang tidak keluar rumah dalam masa iddah dapat mengakibatkan mafsadah bagi orang sekitar. Contoh kecilnya perempuan yang berprofesi sebagai bidan, secara otomatis dia harus selalu siap standby untuk kebutuhan perempuan lain yang akan melahirkan atau dalam proses penanganan pra dan pasca perempuan melahirkan tersebut.

Selanjutnya, ulama Syafi'iyyah mengembangkan batasan keluar rumah bagi perempuan iddah wafat berupa kebolehan keluar rumah sepanjang dalam kebutuhannya dalam waktu ikhtiar, menjadi angin segar bagi perempuan masa kini, sehingga perempuan tetap bisa aktif memberikan kemanfaatan pada orang lain selagi harta peninggalan suami masih tersisa banyak.

Berdasarkan pada batasan operasional Imam Ghazali dalam peng- 
gunaan maslahah mursalah, hukum boleh keluar rumah bagi perempuan iddah wafat karena perempuan dalam kondisi darurat atau karena hajat kebutuhan perempuan tersebut termasuk dalam bidang operasional maslahah mursalah. Sebab hukum keluar rumah bagi perempuan iddah wafat yang dikemukakan di atas sejalan dengan tujuan penetapan hukum Islam, yakni memelihara jiwa. Maslahah tersebut juga tidak bertentangan dengan Alquran dan Sunnah, karena tidak didapati nash shârih yang menyebutkan larangan keluar rumah bagi perempuan iddah wafat.

Selain itu, hukum keluar rumah bagi perempuan iddah wafat disertai pengukuhan oleh teori lain bahwa keluar rumah bagi perempuan yang ditinggal mati suami dibutuhkan untuk menyegarkan pikirannya kembali dan untuk mencegah psikomatik dalam jiwa perempuan yang ditinggal suaminya.

Limitasi keadaan perempuan iddah wafat harus dalam keadaan hajiyah atau daruriyah tidak tahsiniyah sesuai dengan poin ketiga batasan operasional al-Ghazali yang menyatakan bahwa maslahah harus menempati level dharûriyah (primer) atau hajiyah (sekunder) yang setingkat darurat.

Hukum tersebut di atas juga mencakup hal yang bersifat umum bukan bersifat individual, karena setiap perempuan punya kebutuhan yang mengharuskan keluar rumah. Tidak hanya satu dua orang perempuan saja, utamanya perempuan aktivis publik.

Kemaslahatan limitasi perempuan iddah wafat harus dalam kondisi dharuriyah atau hajiyah tidak dalam kondisi tahsiniyah, adalah kemaslahatan yang sejalan dengan tujuan penetapan hukum Islam, yakni mendatangkan kemaslahatan dan menghindari mafsadat, sebagaimana kaidah fiqih "menolak mafsadah didahulukan daripada meraih maslahat". Jika perempuan diwajibkan tetap diam di rumah tanpa ada pengecualian boleh keluar rumah dalam waktu ikhtiar, tentu hal tersebut dapat mendatangkan mafsadat, semisal perempuan yang ditinggal mati bertambah stres atau mendatangkan mafsadat bagi kemaslahatan orang lain.

Sebagaimana yang telah dipaparkan di atas, dapat disimpulkan 
bahwa hukum keluar rumah bagi perempuan iddah wafat sejalan dan tidak bertentangan dengan batasan operasional maslahah mursalah yang dikemukakan Imam Ghazali.

Penetapan limitasi hukum keluar rumah bagi perempuan iddah wafat bahwa perempuan iddah wafat boleh keluar rumah sepanjang kebutuhan perempuan tersebut mengharuskan keluar rumah. Dapat dijumpai kesamaan produk hukum antara empat mazhab walaupun dalam teksnya keempat mazhab tersebut berbeda proses istinbathnya.

Mazhab Hanafi menerima dan menggunakan maslahah mursalah dalam menetapkan suatu hukum. Dalam hal keluar rumah bagi perempuan iddah wafat, mazhab Hanafi menggunakan teori maslahah mursalah untuk menetapkan hukumnya. Hal tersebut terlihat karena mazhab Hanafi tidak menggunakan dalil Alquran dan hadits yang shârih sebagai pijakan penetapan hukumnya.

Berbeda dengan mazhab Syafi'i yang secara teks menolak menggunakan maslahah. Dalam kenyataannya penetapan hukum mazhab Syafi'iyah dapat ditemui beberapa indikator yang mengindikasikan bahwa mazhab ini sebenarnya menggunakan poin-poin yang menjadi keharusan utama dalam pemakaian teori maslahah mursalah. Akan tetapi mazhab Syafi'iyah menetapkan hukum keluar rumah ini dengan alasan memutlakkan antara hukum perempuan iddah wafat dan perempuan iddah talak.

\section{Penutup}

Bagi perempuan iddah wafat boleh keluar rumah pada waktu ikhtiar untuk kebutuhan yang mengharuskan keluar rumah pada pagi hari. Dan pada waktu darurat boleh keluar rumah kapan saja. Penetapan hukum keluar rumah bagi perempuan 'iddah wafat ditinjau dari analisis maslahah mursalah, dalam kondisi dharûriyah atau hajiyah adalah tidak bertentangan dengan batas operasional maslahah mursalah. Mazhab Syaf'i sebagai mazhab yang menolak menggunakan maslahah, dalam kenyataannya tidak menolak maslahah mursalah secara mutlak. Imam Ghazali sebagai imam dengan haluan Syafi'iyyah menggunakan maslahah mursalah dengan menetapkan batas operasional maslahah mursalah. 
Dalam penetapan hukum keluar rumah bagi perempuan iddah wafat menurut mazhab Syafi'iyah dapat ditemui beberapa indikasi yang sejalan dengan indikator-indikator penggunaan teori maslahah mursalah oleh mazhab lain.

\section{Pustaka Acuan}

Arsjad, Rasyida. "Iddah, Antara Agama dan Budaya (Studi Kasus Iddah Wafat di Kecamatan Sangkapura)", Jurnal Lentera: Kajian Keagamaan, Keilmuan dan Teknologi 3, no. 1, (Maret 2017), h. 144.

As-Siddiqi, Hasbi. Pengantar Hukum Islam, Vol. 01, Jakarta: Rajawali, 2009. Atabik, Ahmad. "Kontradiksi antar Dalil dan Cara Penyelesaiannya Prespektif Ushuliyyin.” YUDISIA: Jurnal Pemikiran Hukum dan Hukum Islam 6, no. 2 (2015), h. 263

Bisri, Abdul Mukti. "Konsep Ta'aqquli dan Ta'abbudi dalam Tafsir," Akademika 8, no. 2 (2014): h. 231-240.

Bugha, Syeikh Mustafa al-. Al-Fighul Manhaji, Jilid IV, Bayrut: Dar al-Fikr, t.t.

Dahlan, Abdur Rahman. Ushul Fiqh. Jakarta: Kencana, 2010.

Djazuli, A., Ilmu Figh. Bandung: Orba Shakti, 1991.

Ghazali, al-. Al-Mustashfa min Ilmil Ushul. Bayrut: al-Risalah, 1997.

Husin, Syh Noorul Madihah Syed, dan Raihanah Azahari, "Pendekatan Islam dalam Memelihara Maslahah Wanita Selepas Kematian Suami." Jurnal Syariah 18, no. 3 (2010), h. 482.

http://kupang.tribunnews.com/2016/01/07/pertumbuhan-jumlah-pekerjaperempuan-meningkat. Desember 2017.

Habibie, Bacharuddin Jusuf. Habibie dan Ainun. Jakarta: THC Mandiri, 2012.

Hartono, "Kompilasi Fatwa Ulama tentang 'Iddah Wanita Hamil Karena Zina dan Kebolehan Menikahinya: Studi Komparatif Mazhab Syafi'iyyah dan Madzhab Hanabilah.” PhD diss., Universitas Islam Negeri Maulana Malik Ibrahim, 2012.

Herawati, Andi. "Maslahat Menurut Imam Malik dan Imam al-Ghazali 
(Studi Perbandingan).” Diktum: Jurnal Syariah dan Hukum 12, no. 1 (2014): 42-53.

Indar. "Iddah dalam Keadilan Gender," YIN YANG Jurnal Studi Gender dan Anak 5, no. 01, (Juni 2010).

Ismail, Habib, dan Nur Alfi Khotamin "Faktor dan Dampak Perkawinan Dalam Masa Iddah (Studi Kasus di Kecamatan Trimurjo Lampung Tengah)." Jurnal Mahkamah: Kajian Ilmu Hukum dan Hukum Islam 2, no. 1 (2017): 135-160.

Jamaa, La. "Konsep Tảabbudi dan Tảaqquli dan Implikasinya Terhadap Perkembangan Hukum Islam.” Asy-Syir'ah 47, no. 1 (2013).

Jamhuri, dan Izzudin Juliara Izzudin Juliara, "Penggabungan 'Iddah Wanita Hamil dan Kematian Suami (Analisis Terhadap Pendapat Mazhab Syafi'i)." SAMARAH: Jurnal Hukum Keluarga dan Hukum Islam 1, no. 1 (2017): 226-247.

Jumantoro, Totok. Kamus Ushul Fikih. Jakarta: Amzah, 2009.

Khaeruman, Badri. "Al-Qaradawi dan Orientasi Pemikiran Hukum Islam untuk Menjawab Tuntutan Perubahan Sosial.” Wawasan: Jurnal Ilmiah Agama dan Sosial Budaya 1, no. 2 (2016), h. 237.

Kholis, Nur. "Antisipasi Hukum Islam dalam Menjawab Problematika Kontemporer (Kajian Terhadap Pemikiran Maslahah Mursalah alGhazali)." Al-Mawarid 10, (2003).

Koto, Alaiddin. Ilmu Fikih dan Ushul Fikih. Jakarta: RajaGrafindo Persada, 2004.

Laluddin, Hayatullah, Mohamad Nasran Mohammad, Zuliza Mohd Kusrin, Shofian Ahmad, Zaini Nasohah, Mohd Zamro Muda, Md Yazid Ahmad, and Ahmad Muhammad Husni. "An Analysis on Maslaha's Development Through of al-Ghazali Pre and Post alGhazali Periods." International Business Management 6, no. 2 (2012): 187-193.

Lestari, Sri. Psikologi Keluarga. Jakarta: Kencana, 2012.

Maliubury, Zainuddin al-. Fath al-Müin. Surabaya: Al Haramain, t.t.

Maraghi, Ahmad al-. Tafsir Al Maraghi, Jilid II, Mishr: Mustafa Al Halabi, 1974. 
Mohammadi, Fatemeh, dkk, "A Comparative Study of the Iddah (Waiting Period) in Iran Jurisprudence and the Laws of Other Countries," International Research Journal of Applied and Basic Science (IRJABS) 6, no. 2, h. 237.

Nawawi, Ismail. Fikih Muamalah. Bogor: Ghalia Indonesia, 2012.

Nurdin, Zurifah. Ushul Fiqih 1. Jakarta: Rajawali, 2012.

Razi, Fakhruddin al-. Al Mahsul, Jilid II, Bayrut: Dar Kattab Ilmiah, t.t. Robbani, Imdad, dkk. Formulasi Nalar Fiqh. Surabaya: Khalista, t.t.

Sabiq, Sayyid. Fiqih Sunnah. Surabaya: Al Haramain, t.t.

Shihab, M. Quraish. Tafsir Al Misbah, Jilid XIII, Jakarta: Lentera Hati, 2000.

Syarifuddin, Amir. Ushul Fiqh, Jilid II, Jakarta: Kencana, 2009.

Syâthibi, Abu Ishak al-. Al-I'tisham, Jilid II, Bayrut; Dâr al-Ma’rîfah, 1975. Tihami, dkk, Fikih Munakahat. Jakarta: Rajawali Pers, 2010.

Turmudzi, Imam. Sunan al-Turmudzi, Jilid IV, Bayrut: Dar Kattab Ilmiah, t.t.

UU No. 1 tahun 1974 tentang Perkawinan. Bandung: Citra Umbara, 2009.

Umam, Chaerul, dkk, Ushul Fiqih. Bandung: CV. Pustaka Setia, 2000. Yaqin, Ainol. "Urgensi Tarjîh dalam Istinbath Hukum Islam." AlIhkam: Jurnal Hukum dan Pranata Sosial 10, no. 1 (2015), h. 113-114.

Yusuf, Muhammad. "Relevansi Pemikiran Ulama Bugis dan Nilai Budaya Bugis (Kajian Tentang 'Iddah dalam Tafsir Berbahasa Bugis Karya Mui Sulsel)." ANALISIS: Jurnal Studi Keislaman 13, no. 1 (2017): 57-78.

Zaelani, Abdul Qodir. "Konsep Tảaqquli dan Tảabbudi dalam Konteks Hukum Keluarga Islam.” Asas: Jurnal Hukum dan Ekonomi Islam 6, no. 1 (2014).

Zahra, Abu. Ushul Fiqih. Surabaya: Al Hidayah, t.t..

Zulaikha, Siti. “Iddah dan Tantangan Modernitas”, Jurnal Hukum Istinbath 7, no. 1, (Mei 2010), h. 96. 
Zuhaily, Wahbah. Figh Islam wa Adillatuhu, Jilid VII, Bayrut: Darul Fikr, 2014. 